e ISSN-0976-7223 | Visit Us - www.researchjournal.co.in

DOI : 10.15740/HAS/IJAE/7.2/299-306

\title{
Nutrient dynamics as influenced by different levels of drip and surface irrigation methods in the rhizosphere of beetroot crop under saline vertisols
}

SUBHAS BALAGANVI, M.V. RANGHASWAMI, P. BALAKRISHNAN AND S.B. SALIMATH Received : 01.07.2014; Revised : 20.07.2014; Accepted : 04.08.2014

See end of the Paper for authors' affiliation

Correspondence to :

SUBHAS BALAGANVI

Department of Agricultural Engineering, College of Agriculture, Hanumanamatti, HAVERI (KARNATAKA) INDIA Email : subhasuasd@ rediffmail.com
- ABSTRACT : A study was conducted at the Agricultural Research Station, Gangavati, in northern Karnataka, India during Rabi/summer, 2007-'08 and 2008-'09 with beetroot (Beta vulgaris) as the test crop in saline vertisol. During both the year and irrespective of the soil salinity levels slightly higher nitrogen was observed at $15 \mathrm{~cm}$ away from the dripper point compared to either at the dripper point or distances beyond $15 \mathrm{~cm}$ from the dripper point. The magnitude of available nutrients decreased vertically with increase in soil depth. The drip irrigation scheduled at 1.2 ET resulted in the maximum tuber yields of 19.43 and $18.91 \mathrm{t}$ ha $^{-1}$ during 2007-'08 and 2008-'09, respectively. Among the salinity levels, the highest tuber yield of 18.23 and $17.89 \mathrm{t} \mathrm{ha}^{-1}$ were recorded in salinity level-I, respectively. Whereas among the surface irrigation levels, irrigation at 1.2 ET recorded the highest tuber yields of 12.2 and $11.84 \mathrm{t} \mathrm{ha}^{-1}$, respectively.

- KEY WORDS : Drip, Surface irrigation, Vegetable, Beetroot, Soil salinity, Potassium distribution

— HOW TO CITE THIS PAPER : Balaganvi, Subhas, Ranghaswami, M.V., Balakrishanan, P. and Salimath, S.B. (2014). Nutrient dynamics as influenced by different levels of drip and surface irrigation methods in the rhizosphere of Beetroot crop under saline vertisols. Internat. J. Agric. Engg., 7(2) : 299-306. 